\title{
Beyond Donation: China's Policy Banks and the Reshaping of Development Finance
}

\section{Muyang Chen ${ }^{1}$}

Published online: 8 August 2020

(C) The Author(s) 2020

\begin{abstract}
This paper seeks to demystify and characterize China's official development finance by examining lending mechanisms of China's two policy banks - China Development Bank and Export-Import Bank of China. Using quantitative and qualitative data, the paper shows how and why policy banks implement a peculiar means of development finance, i.e., funding projects in developing countries with relatively high-interest rate loans, differing from low-interest rate development-finance credits from industrial countries. The paper argues that China's official development finance is not only about practicing economic statecraft or facilitating export-led growth; it is also the internationalization of a development-finance model that has facilitated its own development in the past decades. In this model, the state does not play a direct role in allocating fiscal revenue; rather, it plays an indirect role in enhancing creditworthiness of projects and making them financially viable. The "state-supported, market-based" Chinese credits reshape development finance and offer an alternative option for the developing world.
\end{abstract}

Keywords Development finance $\cdot$ Policy Bank $\cdot$ China $\cdot$ Infrastructure $\cdot$ Role of the state

\section{Introduction}

In the past decades, China has been massively financing railways, bridges, power plants, ports, and various other infrastructure projects in the developing world. Though heatedly debated and discussed, the nature of these infrastructure loans remains controversial in academic writing, policy analyses, and media reports. Sometimes they are perceived as government-led aid, pursuing geopolitical objectives while supporting international development, whereas other times they are seen as commercially driven investments, propelling the global venture of Chinese firms. This paper seeks to dissect

Muyang Chen

cmuyang@pku.edu.cn

1 School of International Studies, Peking University, No. 5 Yiheyuan Road, Beijing 100871, China 
China's official development finance (ODF) by answering two questions - what these Chinese credits really are and why they are disbursed in a peculiar way.

Examining the major agencies that handle the infrastructure loans, i.e., China's two policy banks, the China Development Bank (CDB) and the Export-Import Bank of China (Chexim), this paper presents two findings, one descriptive and one explanatory. First, the nature of China's ODF is a mixture of official aid and export credits. In terms of lending destinations, these credits are aid-like and flow mostly to the developing regions, but in terms of their terms and conditions, they appear commercial, i.e., in most cases the loans are non-concessional and surprisingly costly. This contrasts starkly with the infrastructure lending of advanced industrial countries: market-rate commercial capital targets projects in developed economies, whereas subsidized, concessional credits finance underdeveloped economies.

Why, then, does China practice ODF in such a peculiar way, i.e., financing the less developed regions with relatively costly capital? The economic statecraft and the developmental state literatures present two rationales behind China's ODF_-pursuing the state's political and foreign policy objectives and facilitating firms' international competition. While these two prevailing explanations explicate some aspects of China's ODF, none could explain the relative high interest rate of Chinese loans. This paper offers a third rationale, arguing that China's peculiar means of ODF is affected by the country's own experience growing as a developing economy, one that needed capital to urbanize and industrialize but lacked the fiscal capacity to finance these processes. China's global infrastructure boom is the internationalization of a development-finance model that has facilitated its own growth in the past decades. In this model, the state participates in infrastructure financing not through direct allocation of fiscal revenue, but through enhancing creditworthiness of projects and making them financially viable to the market. This "state-supported, market-based" means of development finance explains the relative costliness of the Chinese ODF.

This paper makes several contributions. First, it presents the components and characteristics of Chinese ODF through triangulating various sources of quantitative and qualitative data. Due to the fact that very limited first-hand official data of China's ODF is publicly available and that major Chinese financiers have been cautious in discussing their operations in public, the real lending rationales behind these Chinese credits remain opaque. Detailing the policy banks' lending mechanisms as well as their interaction with government organs and firms, this research contributes to the empirical research on China's ODF.

Second, the paper advances the conceptualization of China's ODF. Most interpretations of China's ODF highlight its "statist" nature, perceiving it as party-led, politicallymotivated, or state-subsidized (e.g., Norris 2016; Hopewell 2019). This paper does not deny the high degree of state involvement in China's ODF, but through examining how the policy banks employ various market means to achieve state goals, it shows that "market oriented-ness" is as important as "state-ness" in characterizing the Chinese credits.

By doing so, the research furthers our understanding of development finance. Much existing scholarship has pointed out that China's ODF, or credits from emerging development partners broadly speaking, is more than just official state-led aid defined by concessionality (Chin and Quadir 2012; Mawdsley 2012; Bräutigam and Gallagher 2014; Lin and Wang 2017; Stallings and Kim 2017; Chin and Gallagher 2019). Along 
the same line, this research shows how China reshapes traditional means of "development finance" by demonstrating a mutually-reinforcing state-market relation in development.

This research uses both quantitative and qualitative data. Quantitative first-hand data are obtained from publicly accessible annual reports, financial almanacs, and historical documents. Since the two policy banks as well as other official Chinese sources normally publish aggregated data only and limited data by sector, region, or project, when official data is unavailable, the research uses secondary data collected by research institutes, namely, AidData compiled by William and Mary College and China's Global Energy Finance data compiled by the Global Development Policy Center.

Qualitative data are obtained from interviews with as well as articles/books by people working or who used to work in related fields. The author conducted 57 interviews in China in September-December 2016 and August-September 2017, interviewing people working or who used to work in policy banks, other related financial agencies and organizations, enterprises that are clients of the banks, and government organs engaged in development finance. Interviews with the policy banks were conducted with bank officials of various ages, administrative levels, departments, and branches. Not all of the interviews were cited in this paper, and the majority of interviews were off the record.

The rest of the paper proceeds as follows. The first section examines existing discussions and analyses that capture and theorize China's ODF and the rationales behind it. The second section characterizes China's ODF by detailing the volumes, costs, conditions, and destinations of the Chinese credits with reference to an OECD framework. The third and fourth sections explain why China's ODF is practiced in its peculiar way by focusing on the policy banks and their interactions with government organs and firms. Specifically, the third section looks at the policy banks through the lens of economic statecraft and developmental state literature, and discusses what aspects of the lending can and cannot be explained by these two prevailing explanations. Based on the analysis, the fourth section puts forward a development rationale, explaining why understanding China's domestic financing model could help us understand the non-concessionality of its ODF. The last section concludes the paper.

\section{Theorizing China's Official Development Finance}

Official development finance (ODF) includes different types of credits. In many cases, it refers to official aid, i.e., grants and concessional loans that support development of recipient countries. It also includes export credits that aim to facilitate exports of lending countries' firms. The two nonetheless hold fundamentally different lending incentives: aid is charitable, whereas export credits are commercially driven. Failure to identify the nature of these credits may lead to misleading interpretations of the political and economic rationales behind ODF.

Existing estimations of China's ODF vary from one another. Some tracks China's foreign aid (Kitano and Harada 2014; Kitano 2016); some calculates China's “official finance" (see AidData); some includes aid, loans, and FDI (see China-Africa Research Initiative); and some compiles policy-bank loans (see Global Development Policy Center). Various analyses based on these estimations point out two facts about China's 
ODF. First, multiple types of credits exist and there is no standardized way to categorize them. Second, and quite counterintuitively, the majority of China's ODF in developing countries is not aid and not subsidized (Bräutigam 2011; Bräutigam and Gallagher 2014; Dreher et al. 2017). These findings lead to a question: why does China use nonsubsidized credits to finance development projects, which (1) appear commercially nonviable and (2) according to existing international norms should either be financed by concessional loans/grants or not financed at all?

The economic statecraft literature (e.g., Baldwin 1985; Mastanduno 1999) provides a perspective to understand these official credits, viewing them as economic instruments of the state that serve to achieve foreign policy, geopolitical, security, and strategic goals. The United States' foreign aid in the Cold War era, for example, was perceived in some political science literature as a foreign policy tool to ally with the third world (Liska 1960; Morgenthau 1962; Baldwin 1966). Similarly, some see China's ODF as part of China's economic statecraft, pursuing state objectives beyond pure financial interests (Alves 2013; Reilly 2013; Norris 2016; Katada and Liao forthcoming). Other research on China's ODF, nevertheless, shows that an almighty state deploying economic actors is a false illusion. The state is fragmented and decentralized, and various actors such as state-owned enterprises, local governments, and business groups leverage on the party state's Belt and Road Initiative to pursue their own interests (Jones and Zou 2017; Ye 2019; Liao 2019; Li and Zeng 2019). Along the same line, this paper shows that policy banks have their own interests when implementing ODF and do not necessarily sacrifice financial feasibility in favor of the state's diplomatic or foreign policy goals.

The developmental state literature, grounded on empirical studies of catching-up economies such as Japan and South Korea, offers another explanation by highlighting the state's coordinating role in practicing industrial policy and facilitating exports (Johnson 1982; Amsden 1989, 2001; Wade 1990; Haggard et al. 1993; Evans 1995; Woo-Cumings 1999; Solís 2004; Thurbon 2016; Haggard 2018). Backed up by the state, a selected group of enterprises are able to access low-cost capital and thereby compete with their foreign rivals with greater price advantages. This literature explains a large part of China's ODF: a considerable volume of the Chinese credits was lent to selected enterprises of important industries, and policy-bank lending assisted the global competition of Chinese enterprises (Liou 2014; Hopewell 2019). Nonetheless, the bulk of non-subsidized loans remains unexplained - most of China's ODF loans, counterintuitively, are quite costly.

The peculiar way policy banks implement ODF, i.e., using non-subsidized capital to finance projects in less-developed regions, therefore allows us to reconsider the meaning of development finance. Traditional means of aid-giving or concessional lending implies a transfer of wealth from donors to recipients, since the margin between the interest rate of a concessional and that of a market loan has to be subsidized by donors/lenders. Such a charitable practice was supported by theories of development economics in the 1950s and 1960s, which highlighted the importance of large investment capital in jumpstarting economic growth (e.g., Lewis 1954; Rosenstein-Rodan 1961; Rostow 1963). In the same era was the establishment of the World Bank's International Development Association (IDA) and the OECD-Development Association Commission, two international organizations that have been regulating and disbursing soft loans and aid to the developing world (Kapur et al. 1997; Schmelzer 2014). 
The rationale behind this postwar aid regime was that with the assistance of "advanced" economies, "backward" economies could develop. Such a donation-based means of development finance was criticized for being inefficient, resulting in market distortions and causing debt issues in recipient countries, and was challenged by more reciprocal means of aid-giving by emerging donors, including China (Bauer 1968; Easterly 2003, 2006; Six 2009; Sato et al. 2011; Mawdsley 2012; Chin and Quadir 2012; Ohno and Ohno 2013; Edwards 2014; Stallings and Kim 2017).

Yet, China is not only an emerging "donor." The majority of Chinese ODF, as the "Estimating China's ODF Using OECD Definitions" section will show, is not aid and is not perceived as "aid" in China. Xu and Carey (2015) conceptualize Chinese credits using an idea of "public entrepreneurship," i.e., "scaled-up, market-based official finance especially from developing economies." Lin and Wang (2017) argue that China is going beyond aid through development cooperation for structural transformation and call for a broadening of the OECD's definition of Official Development Assistancenon-concessional export credits should also be calculated since they too contribute to development. Chin and Gallagher (2019) find that China globalizes its development finance through the overseas diffusion of a coordinated credit space model that blends concessional and non-concessional lending by China's government ministries, policy banks, and commercial banks. This strand of emergent literature highlighting the overlooked duality of China's ODF unveils the internationalization of China's own development-finance model, one that is not only state-led, but also market oriented. In the same vein, this paper adds nuances to the conceptualization of China's ODF and development finance broadly speaking by focusing on the costliness of Chinese credits and showing how policy banks downplayed the state's direct role in credit allocation and adopted market instruments to finance development.

\section{Estimating China's ODF Using OECD Definitions}

\section{The OECD Definitions}

The OECD defines a variety of official development-finance credits (Fig. 1). The most widely known is Official Development Assistance (ODA), which has to meet three criteria: (1) official, "provided by official agencies, including state and local governments, or by their executive agencies;" (2) concessional, having lower-than-market interest rates or longer grace periods; and (3) developmental, contributing to the "economic development and welfare of developing countries," as opposed to serving donors' commercial interests. ${ }^{1}$

Two types of official loans do not fall under the definition of ODA and are categorized as Other Official Flows $(\mathrm{OOF})^{2}$ : (1) non-concessional development loans: loans offered by an official agency but do not meet the concessional condition and (2) export credits: loans/guarantees offered by an official export credit agency (ECA) but

\footnotetext{
1 "Official development assistance - definition and coverage," OECD, http://www.oecd. org/dac/stats/officialdevelopmentassistancedefinitionandcoverage.htm.

2 "Resource flows beyond ODA in DAC statistics," OECD, http://www.oecd.org/dac/financing-sustainabledevelopment/development-finance-standards/beyond-oda.htm. "Non-ODA flows to developing countries: Export credits," OECD, http://www.oecd.org/dac/stats/beyond-oda-export-credits.htm.
} 


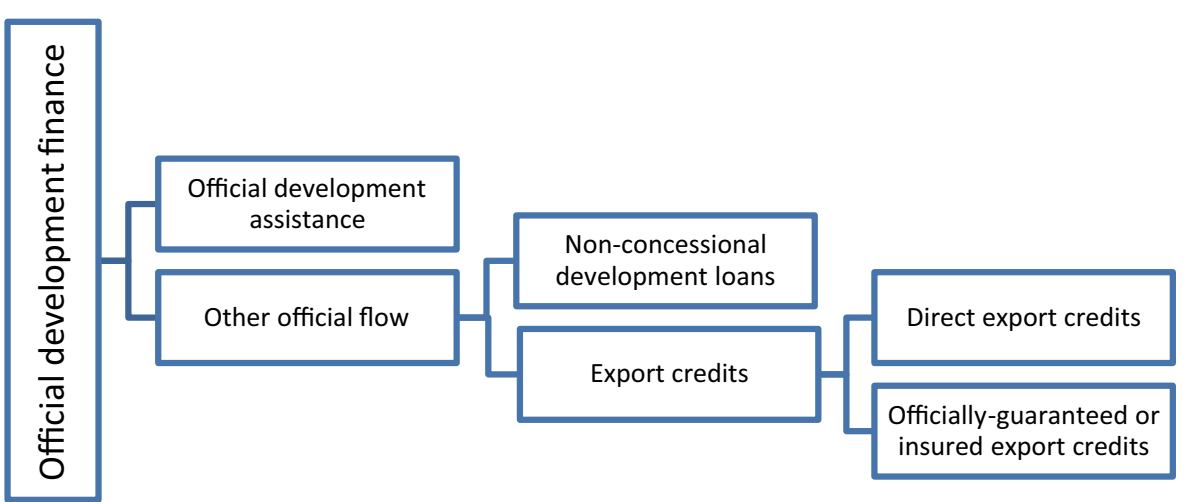

Fig. 1 Typology of official development-finance credits; source: author's formulation

not necessarily for recipient's development. Export credits consist of two categories: (1) direct export credits: "loans extended by ECAs to facilitate and encourage exports to developing countries" and (2) officially guaranteed or insured export credits: "loans extended by the private sector but guaranteed/insured by ECAs to finance an export transaction."

Though explicitly defined, the boundaries between these credits are rather blurry in real practice, and the reason is mainly twofold. First, the quantification of concessionality is controversial. Second, it is hard to identify objectives of loans, since they may benefit recipient's development while facilitating donor's exports at the same time. As a result of these ambiguities, countries can intentionally mix these credits to achieve certain goals. One commonly observed gray zone is the offering of low interest rate ODA loans to commercially viable projects. By doing so, a country lowers the cost of capital and thereby increases the competitiveness of its firms in international competition.

\section{China's ODF Through the OECD Lens}

China's ODF generally falls into four categories - (1) grants and interest-free loans disbursed and funded by government, (2) concessional loans partly funded by government and disbursed by policy banks, (3) non-subsidized loans disbursed and funded by policy banks, and (4) commercial-bank loans insured by an official insurance company. According to the Chinese government's definition, China's foreign assistance consists of the first two types of credits, i.e., grants and interest-free loans disbursed by the Department of Foreign Assistance of the Ministry of Commerce (MOFCOM) and concessional loans (youhui daikuan) disbursed by the Department of Preferential Loans of the Exim Bank of China (Chexim). ${ }^{3}$ The former is capitalized by the government's tax revenue whereas the latter uses mostly Chexim's self-raised funds. Concessional loans are denominated in renminbi with an interest rate below China's central bank's benchmark rate, and the margin between the two is subsidized by the Ministry of

\footnotetext{
${ }^{3}$ On April 18, 2018, the China International Development Cooperation Agency was inaugurated with the mandate to coordinate foreign assistance and international development cooperation. The new agency assumed the functions of the Department of Foreign Assistance of the Ministry of Commerce. The data on China's foreign assistance presented in this paper is before this administrative restructuring.
} 
Finance (The State Council 2014). In addition to concessional loans, Chexim offers a type of U.S. dollar loan that is also below market interest rate-preferential buyer's credits (youhui maifang xindai). These dollar loans are not calculated as part of China's official foreign aid, because they are financed by the bank's own capital and not subsidized by government funds. The two types of loans combined are termed liangyou loans (literally, "two preferential loans"). They are managed by the same department of Chexim and have interest rates ranging between 2 and 3\%. ${ }^{4}$ MOFCOM's loans/grants as well as Chexim's liangyou loans generally qualify the OECD's definition of ODA, but their aggregated amount is rather limited, less than 5\% of China's total official overseas development finance in 2013 (Fig. 2). Moreover, liangyou loans only compose a minor portion of Chexim's total lending; the majority of its loans have interest rates comparable to market rates.

Another major financier of China's ODF is the China Development Bank (CDB). Despite the fact that the CDB does most of its business at home, its size of overseas lending is the largest among all financial agencies in China. By the end of 2016, the CDB's accumulated lending volume in foreign (non-renminbi) currency took up $30.1 \%$ of China's entire banking sector, which demonstrated the bank's leading role in China's overseas finance. ${ }^{5}$ Interviews with CDB loan managers and employees of enterprises that have received CDB loans suggest that interest rate of CDB loans generally ranges from 3 to $6 \%{ }^{6}$ The bank's self-reported average interest rate of "loans and advances" in 2015 and 2016 was 5.25\% and 4.40\%, respectively (CDB Annual Report 2016a). What is certain is that the CDB does not offer any kind of officially subsidized loans that resemble Chexim's concessional loans. In very rare cases, the CDB may offer an extraordinarily low interest rate. For example, when bidding for a widely reported project-Jakarta-Bandung High-Speed Rail project for which China and Japan competed intensively, China offered an interest rate of $2 \%$ and the capital came from the $\mathrm{CDB}$, according to media reports. But even in such a case, the interest rate offered by China was nowhere comparable to that of Japan, which was only $0.1 \%{ }^{7}$ The policy banks' non-concessional rates are also generally higher than the interest rates provided by the International Bank for Reconstruction and Development (IBRD), the World Bank's lending arm for higher-income developing countries. The IBRD rates are usually $50-150$ basis points above LIBOR, which is around $2-4 \%$ in the recent years. Using the OECD definition, CDB loans and Chexim's non-liangyou loans resemble OOF and not ODA.

Another source of development-finance credits is China's big commercial banks, namely, the Industrial and Commercial Bank of China, the China Construction Bank, and the Bank of China, all listed on stock exchange. These banks co-finance with the policy banks and are playing increasingly important roles in financing overseas development projects (Chin and Gallagher 2019). Despite their state ownership, commercial

\footnotetext{
4 “Liangyou Daikuan Yewu Jishao," Export-Import Bank of China, http://www.chinca. org/cms/html/files/2013-12/16/20131216102948872930302.pdf.

5 "Guokaihang: Tuchu Fuwu Yidaiyilu Jianshe," China Development Bank, http://www.cdb.com. $\mathrm{cn} / \mathrm{xwZX} / \mathrm{khdt} / 201702 / \mathrm{t} 20170204$ 4068.html.

${ }^{6}$ Interest rates of foreign-currency loans are presented in the form of LIBOR $+n \cdot 100 \mathrm{bps}$. Actual interest rates therefore may fluctuate with LIBOR.

7 "Zhongri Zhengduo Yinni Gaotie Zuizhongzhan Jinri Daxiang," Tengxun Caijing, http://finance.qq. com/cross/20150901/5OSn869v.html.
} 


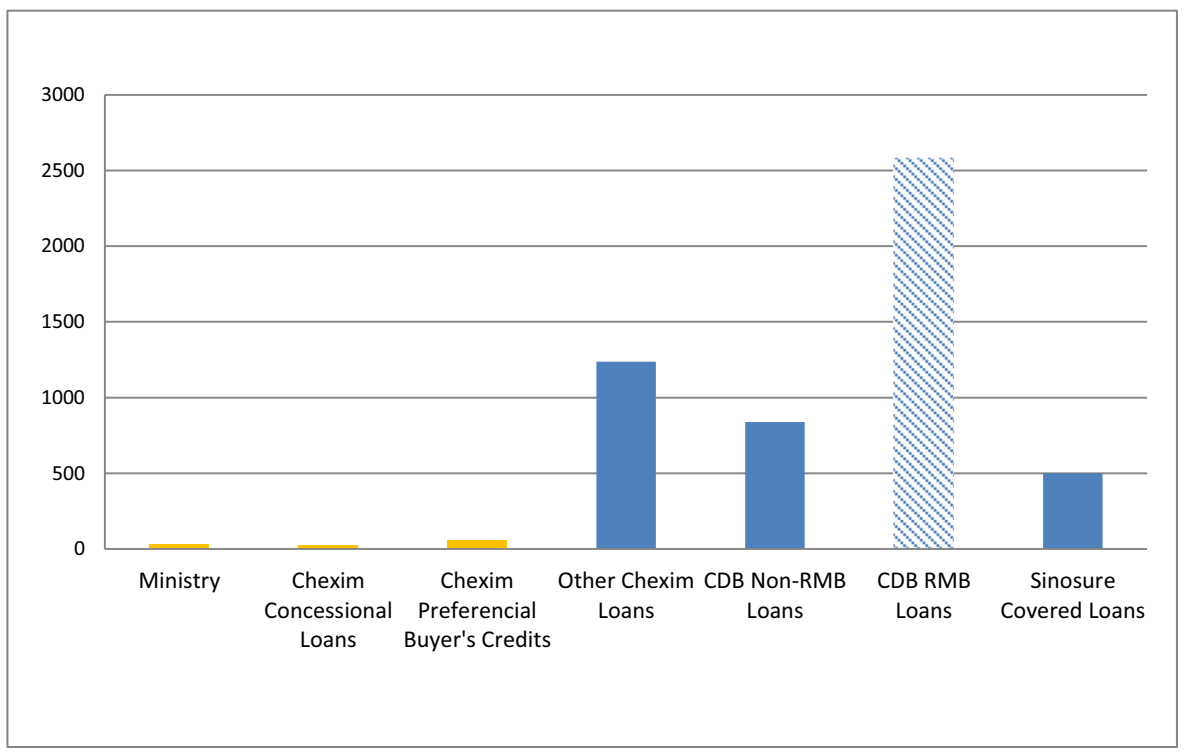

Fig. 2 China's official development-finance credits (in 100 million USD); sources: Ministry of Finance, Almanac of China's Finance and Banking 2014, China Export \& Credit Insurance Corporation 2015

banks are not official ECAs or development banks, nor are their loans subsidized. Therefore, their loans are generally not "official." But according to the OECD definition, a commercial-bank loan can be considered OOF if the project it finances is guaranteed by an official insurance company (another type of ECA). The underlying assumption of this definition is that if project fails, the official insurance company backed up by government revenue would cover the loss. In practice, if a borrower has purchased insurance from an ECA for its project, banks would normally offer a much lower interest rate because the project is guaranteed by sovereign credibility and considered less risky. The Chinese equivalent of insurance ECA is the China Export and Credit Insurance Corporation (Sinosure), which was established in 2001 after a merger of the export credit insurance departments of the People's Insurance Company and of Chexim. As shown in Fig. 2, in 2013, Sinosure insured approximately $\$ 50$ billion overseas development-finance loans (China Export \& Credit Insurance Corporation 2015), ${ }^{8}$ whereas the two policy banks' estimated non-subsidized loans were about \$207.6 billion (Almanac of China's Finance and Banking 2014). However, many of the Sinosure-covered loans were in fact issued by the two policy banks and not by commercial banks. Thus, the volume of China's officially insured commercial-bank loans in 2013 should be smaller than $\$ 50$ billion.

Compared to commercial banks, the two policy banks have an advantage in providing long-term, large-volume loans - an important precondition for infrastructure finance. As Fig. 3 shows, policy banks took up dominant shares (78\%) of medium- and long-term foreign-currency loans among all Chinese banks. ${ }^{9}$ A major contributing factor to this advantage has been the banks' distinctive source of funding - they raise

\footnotetext{
${ }^{8}$ This includes Medium \& Long-Term Export Credit Insurance, Overseas Investment Insurance, Bond and Guarantee Business, and Others.

${ }^{9}$ Medium- and long-term loans refer to loans that are above 1 year
} 


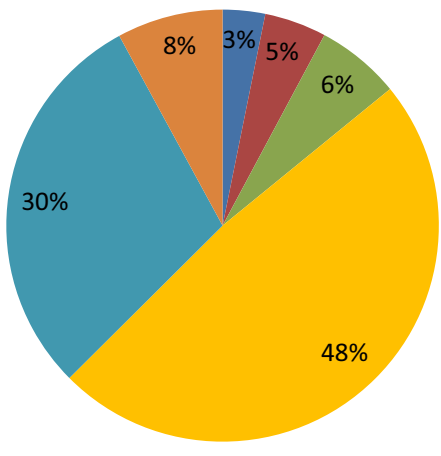

- Industrial and Commercial Bank of China

- China Construction Bank

Bank of China

$\mathrm{CDB}$

Chexim

Other

Fig. 3 Medium- and long-term foreign-currency loans by banks, 2015; source: Almanac of China's Finance and Banking 2015

most of their funds through bond issuance. Policy-bank bonds enjoy "zero-risk weighting," a policy favor granted by the state, and are therefore rated as high as government bonds. Such a sovereign guarantee ensures long-term, large-volume funding and lending (Sanderson and Forsythe 2013; CDB 2013; Chen 2020). Commercial banks, on the contrary, rely mostly on clients' deposits, which can be withdrawn short term. With their unique fund-raising mechanism, policy banks are able to perform peculiar means of finance that regular commercial banks cannot do. For instance, the $\mathrm{CDB}$ conducts portfolio financing, i.e., using bundled loans to finance multiple projects at a time, facilitating urbanization, and equipping cities with a set of public facilities at once (Zou 2014; CDB 2016b). Chexim does less urban financing, but also prefers lending to projects with economic scale, since its major clients are mostly engaged in strategic industries which projects require large-volume investment.

Nonetheless, policy banks do not have an advantage in terms of capital cost. Compared to China's commercial banks, their fund-raising cost is surprisingly high, especially with renminbi loans. The yield of renminbi-denominated policy-bank bonds, which determines policy bank's capital cost, is roughly around 3-5\%, whereas the interest rate on deposits, which determines a commercial bank's capital cost, is only 1$2 \% .^{10}$ In terms of non-renminbi loans, the CDB has two sources. The first is foreign currencies borrowed directly from government organs (e.g., the central bank) at a rate of approximately 2-3\% (CDB Annual Report 2016a). ${ }^{11}$ The other is self-issued foreign-currency bonds, but the volume of issuance is usually limited. In 2016, for example, the bank issued foreign-currency bonds with a total volume equaling 6.5

\footnotetext{
${ }^{10}$ Policy bond yield rate can be found on the official website of China Central Depository \& Clearing co. ltd and interest rate of deposits can be found on People's Bank of China's official website.

${ }^{11}$ According to CDB's annual report, the average interest rate of "borrowings from governments and other financial institutions" was $2.26 \%$ in 2016 and $2.67 \%$ in 2015. By the end of 2016, 9\% of "borrowings from governments and other financial institutions" was in Renminbi, $89 \%$ was in US dollar, and $1 \%$ was in other currencies.
} 
billion USD, whereas its renminbi-bond issuance was 1500 billion (over 200 billion USD) (CDB Annual Report 2016a). Given the low-interest rate capital available on the international financial market, if a Chinese commercial bank can attract sufficient amount of overseas deposit directly, it may be able to offer a much lower interest rate than policy banks do. What this comparison implies is that although on an aggregated level a commercial bank cannot finance as many infrastructure projects as a policy bank does, on a single project, the former is capable of competing with the latter, especially when a project appears lucrative.

To sum up, except for MOFCOM's interest-free loans and Chexim's concessional loans, all other ODF credits, including the policy banks' non-liangyou loans and the large commercial banks' loans, are not subsidized by the government and generally do not have a considerable level of concessionality in interest rates. Compared to commercial banks, policy banks have an advantage in scale, i.e., in issuing large-volume and long-term loans, but the interest rates they offer are not necessarily more concessional given that they raise most of their funds through bond issuance, which is more costly than raising funds from savings, the typical capital source of commercial banks. The interest rates of policy-bank loans are not lower than that of industrialized countries' public financial agencies as well as that of international developmentfinance institutions.

Despite their relative high interest rates, the majority of bank loans have been lent to the developing regions. According to AidData, the top 20 borrowers of Chinese bank loans from 2000 to 2014 were Venezuela, Russia, Pakistan, Belarus, Iran, Nigeria, India, Angola, Brazil, Ecuador, Argentina, Indonesia, Ethiopia, Ghana, Kazakhstan, Laos, Bosnia-Herzegovina, Sri Lanka, the Philippines, and Mali (Fig. 4). ${ }^{12}$ Using the World Bank's income-level categorization, ${ }^{13}$ eight of these borrowers are uppermiddle-income countries, eight are lower-middle-income countries, two are low-income, and none of them is high-income. Global Development Policy Center's dataset shows that from 2000 to 2017, the largest borrowers of China's policy-bank loans in the energy sector were Russia, Brazil, Pakistan, Angola, India, Venezuela, Indonesia, Turkmenistan, Nigeria, Vietnam, Argentina, Ecuador, Cambodia, Ukraine, Bangladesh, the UK, Zambia, Uganda, Bosnia and Herzegovina, and South Africa (Fig. 5). Among these countries, eight are upper-middle-income countries, ten are lower-middle-income countries, one is a high-income and one is a low-income country. In other words, the policy banks have been mostly targeting developing countries.

These regions which China finances with mostly non-subsidized loans, nonetheless, are normally destinations of concessional lending or aid from industrial countries. A comparison to Japan's two public financial agencies illustrates this disparity. Japan has two separate public financial agencies: Japan International Cooperation Agency (JICA), the aid agency, and Japan Bank for International Cooperation (JBIC), the Exim bank. In 2015, JICA distributed $37 \%$ of its ODA to Southeast Asia and the Pacific and

\footnotetext{
12 The original dataset has 5466 entries of development-finance projects. The author took out projects that were financed by government organs (e.g., a ministry), companies, and, organizations and kept projects financed by policy banks, commercial banks, and unspecified financiers; the author also took out grants, interest-free loans, technical assistance, scholarships, debt forgiveness, debt restructuring, and only calculated loans, export credits, supplier credits, and unspecified ones. This added up to 1737 entries.

13 "World Bank Country and Lending Groups," World Bank, ttps://datahelpdesk.worldbank. org/knowledgebase/articles/906519-world-bank-country-and-lending-groups.
} 


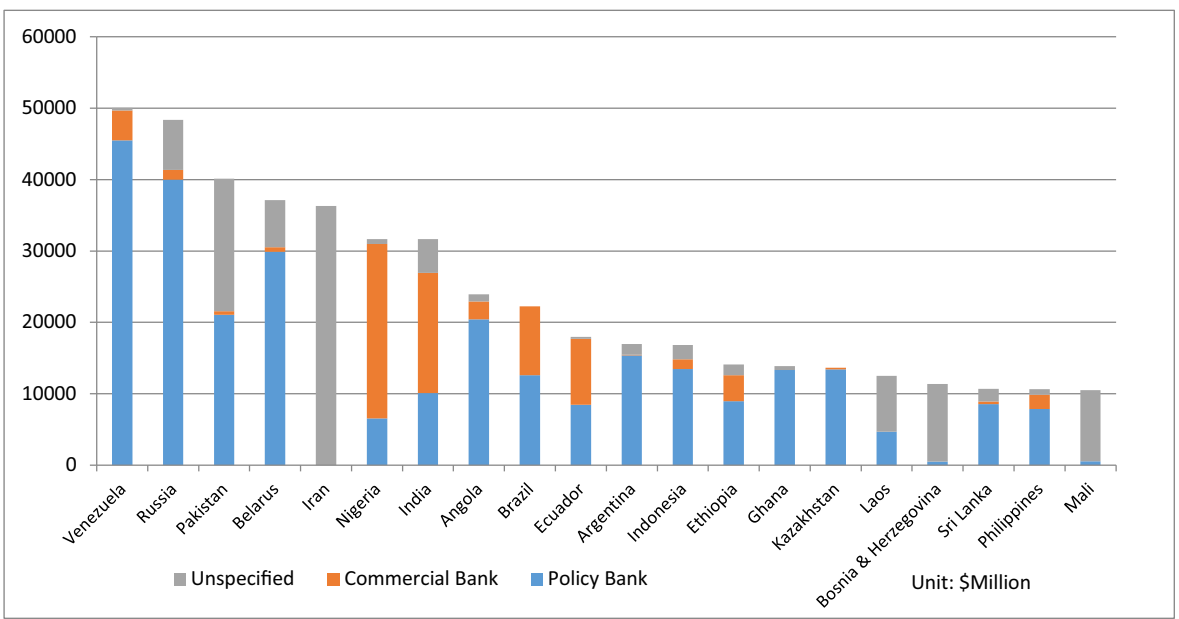

Fig. 4 China's official bank loans 2000-2014; source: AidData. The dataset does not specify whether a commercial-bank loan is insured by an official insurance company or not. This figure therefore may overestimate the total volume of official bank loans by including commercial loans that are not officially insured.

more than half of it went to Vietnam. The region that received the second largest amount of ODA was South Asia and about two-thirds of it went to India (Fig. 6). JBIC, however, demonstrated a contrasting lending preference. It was more interested in developed economies. The region that received most JBIC credits was Europe, and the largest borrower was the UK (Fig. 7).

A similar aid-giving and lending pattern can be found in Germany, the largest European ODA donor. Germany's KfW Group handles both ODA and export credit loans. The KfW Development Bank and the DEG finance development projects, and the KfW-Ipex issues export credits. In 2015, 4.2 billion Euro of Ipex loans financed

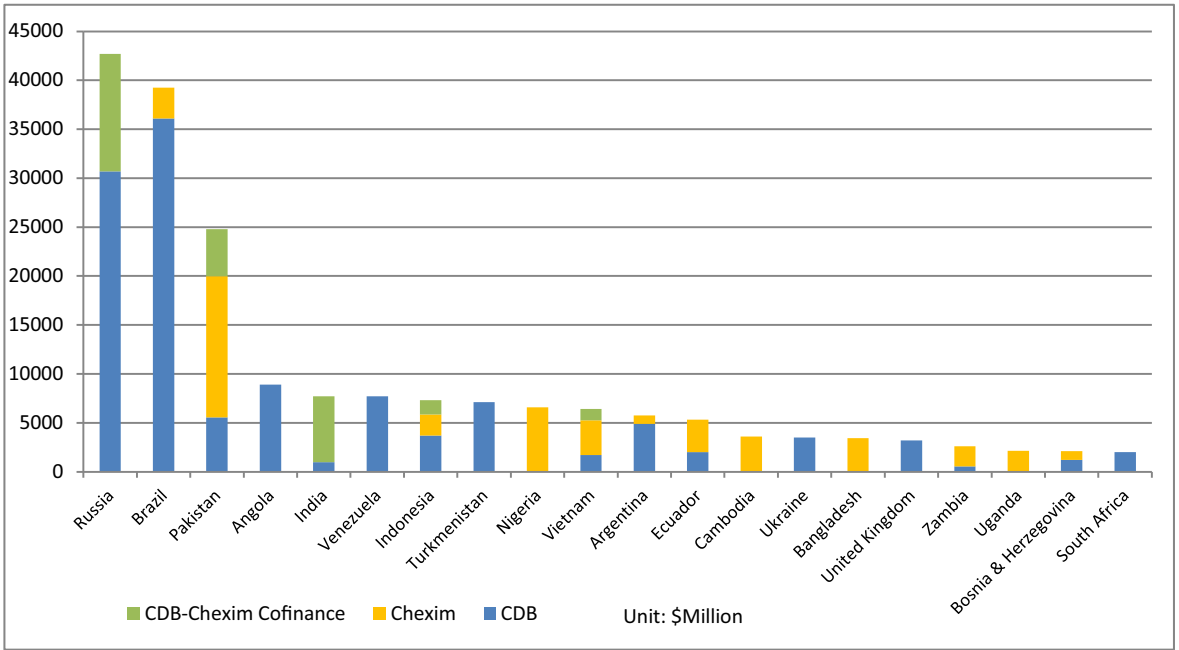

Fig. 5 CDB's and Chexim's lending in energy sector, 2000-2017; source: Global Development Policy Center 


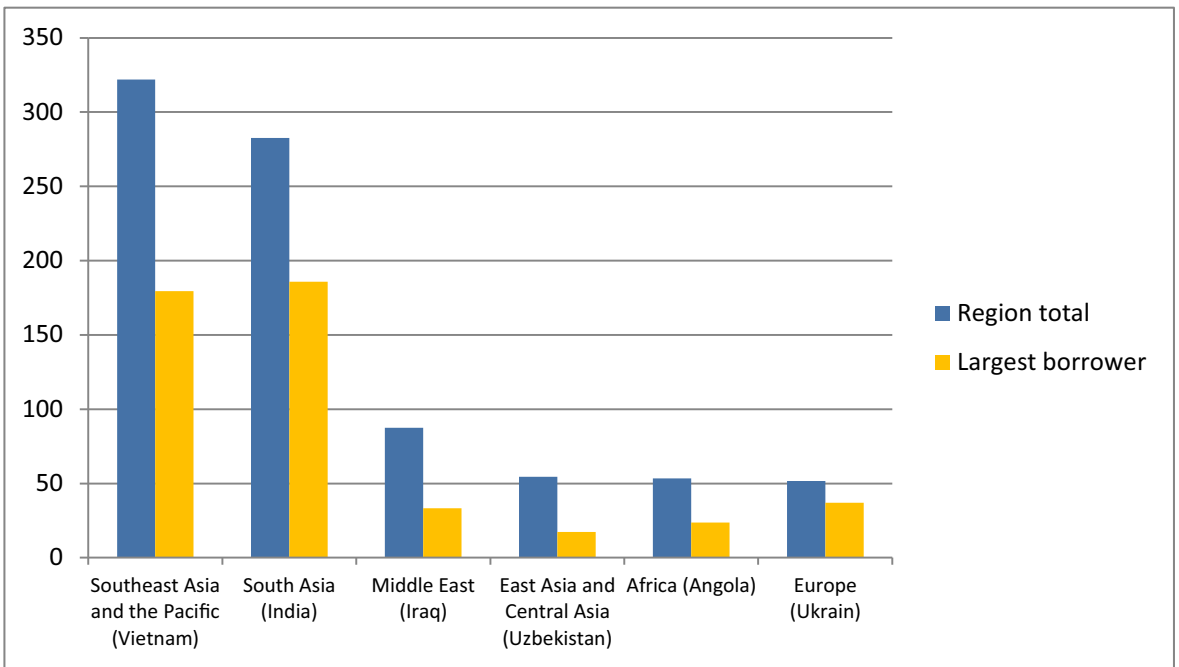

Fig. 6 Japan International Cooperation Agency's ODA by region (in billion yen), Fiscal Year 2015, in billion yen; source: JICA Annual Report 2016

projects within Germany, 6.7 billion flowed to other parts of Europe, and 6.4 billion to the rest of the world (4.8 Euro to emerging markets). In other words, $63 \%$ of the credits stayed in Europe (KfW-Ipex 2016). The KfW Development Bank and the DEG focused on projects in developing countries and emerging markets, and a certain portion of the capital for those projects (e.g., 2.2 billion out of 7.7 billion in 2015) came directly from the federal government (KfW 2016). In 2015, India, Indonesia, and South Africa received most development-finance credits from Germany. ${ }^{14}$ That is to say, like Japan, Germany's export credits favored developed economies. As to projects in less developed regions, where most of China's ODF flowed to, the KfW employed ODA.

To conclude, the above analysis presents three important features about China's ODF. First, the main financiers of China's ODF are the two policy banks. The amount of MOFCOM's foreign assistance is trivial compared to the volume of policy-bank loans. Sinosure-covered commercial-bank loans are another important source but the total volume has been limited by far. Second, most of China's ODF is not concessional in terms of interest rate. Only MOFCOM's grants and interest-free loans and Chexim's liangyou loans offer interest rates below market rate, but these grants and loans altogether account for a small portion of China's total ODF. The major sources of ODF are Chexim's non-liangyou loans and the CDB's overseas loans, both nonsubsidized. Third, the main destinations of the policy-bank loans are developing countries, to which lenders from industrial countries usually offer governmentsubsidized concessional lending or aid/grant only. These three characteristics present a dual nature of China's ODF. In terms of destinations, it is aid-like, because it mainly finances the developing world. However, in terms of conditions, it appears commercial, because most loans are non-subsidized and the capital cost is relatively high in comparison with either foreign loans or Chinese commercial-bank loans.

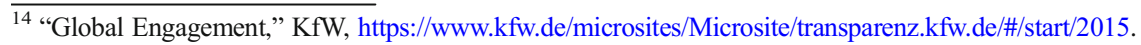




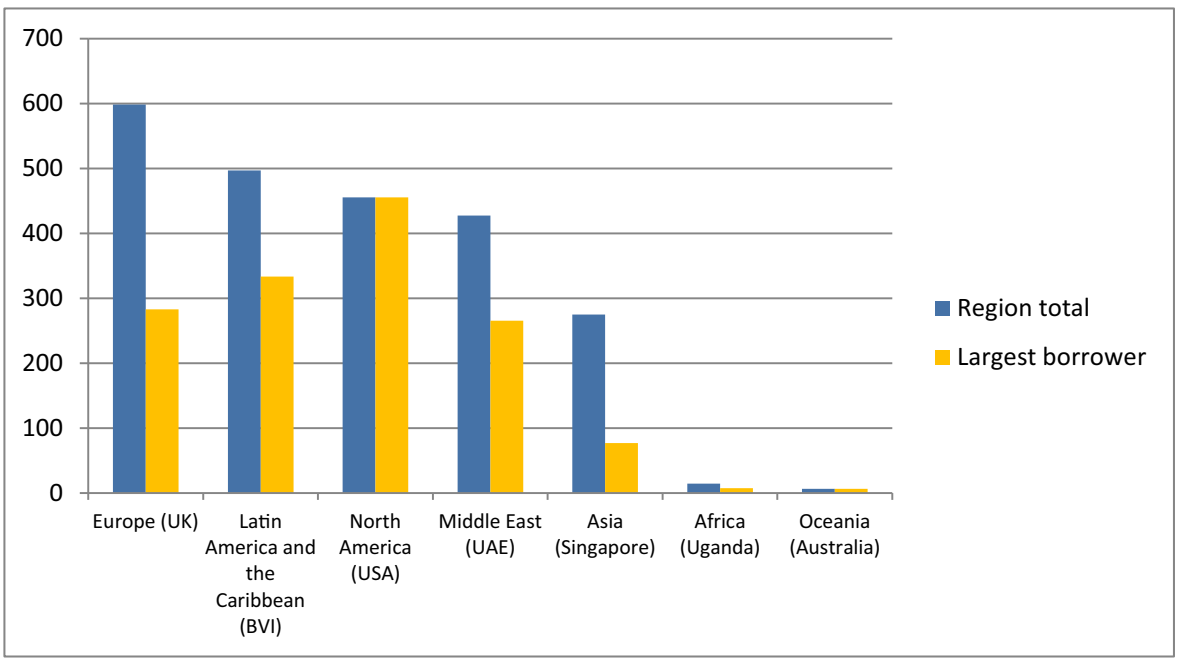

Fig. 7 Japan Bank for International Cooperation's credits by region (in billion yen), Fiscal Year 2015, in billion yen; source: JBIC Annual Report 2016

\section{Explaining China's ODF: The Political-Economic Nexus}

\section{China's Economic Statecraft}

Why do China's policy banks use non-subsidized loans to finance projects that are traditionally financed by low-cost, subsidized lending of industrial countries? As discussed in the first section, one way to answer this question is through the lens of economic statecraft, i.e., perceiving Chinese credits as the state's instruments to achieve geopolitical, diplomatic, security, or strategic goals. In recent years, China's overseas infrastructure financing has often been described as "debt-trap" diplomacy in political commentaries and media reports.

At a cursory glance, policy banks appear to be such economic tools of the state since they are mandated to achieve "policy" goals, but a closer examination shows more complexity with the state-policy bank relation. The party state, which appears to be initiating top-down ODF policies, does not specify its plans in detail. From the onset of the Belt and Road Initiative (BRI) in 2013 to the Belt and Road Summit in 2019, the top leadership of the communist party announced broad ideals such as "openness," "infrastructure connectivity," "trade and investment," and "South-South cooperation." The implementation of these broad ideals lies in the many state and subnational actors. In her analysis of the domestic politics of the BRI, Ye (2019) characterizes the fragmentation of the state in the BRI implementation process: the communist leadership initiated the BRI with broad, vague ideals and mobilized various actors to implement the strategy, major state agencies with power and resource (e.g., ministries of technocrat groups) executed the policy, and lower-level actors (e.g., local governments and business groups) leveraged on the BRI to pursue their own interests. For example, China's Ministry of Foreign Affairs (MOFA) and Ministry of Commerce (MOFCOM) have different priorities when implementing the BRI. The former prioritizes 
foreign affairs whereas the latter prioritizes economic cooperation, though both follow the party's guidelines.

Policy banks' lending is affected by such a state fragmentation-they are "policy" banks following the party state's general policy agendas; they are financial agencies subject to the supervision of China Banking Regulatory Commission, the state's financial regulatory body; and, more importantly, they are powerful state-owned agencies per se with their own priorities. Banking prudence is one of their most important principles - they do not want failed projects or non-performing loans. "When we select projects, we definitely choose the ones with economic effectiveness and feasibility," said Ding Xiangqun, vice governor of the CDB in a BRI meeting in 2017. ${ }^{15}$ This preference for economic feasibility, however, does not always align with non-economic state objectives, i.e., geopolitics, foreign relations, or security, which are the key interests of specific state organs such as MOFA. When different preferences collide, whether policy banks would choose to sacrifice economic feasibility remains questionable.

One commonly observed channel through which state-led diplomacy drives economic collaboration is Gaofang, or top-level visit. An example was the China-Pakistan Economic Corridor (CPEC). The economic-cooperation plan, which would build a collection of infrastructure projects throughout Pakistan, was put forward by China's Prime Minister Li Keqiang during his visit to the country. But such a seemingly top-down mechanism cannot be considered entirely foreign policy driven due to two reasons. First, many projects existed before official visits. For example, Gwadar Port of Pakistan was built before Li's visit in 2013. In many cases, Gaofang reinforced existing economic collaboration rather than generating new projects from scratch. Second, the party leadership only provided a framework for collaboration. It was the banks, firms, and related executive agencies that put the plan into effect, and the projects had to go through regular financial appraisal regardless of their diplomatic significance. For example, in 2017, Pakistan withdrew its request to include the $\$ 14$ billion DiamerBhasha Dam project to CPEC, due to the tight financial conditions offered by China. $^{16}$

Another example was the Jakarta-Bandung High-Speed Rail project previously mentioned. Top-level leadership of both China and Japan were involved in facilitating the deal. The rivalry was widely reported over mass media, considered a competition of the two countries' "reputations." In the end China's package was selected, but the implementation of the project was largely postponed, regardless of its salient diplomatic meaning. One reason was that China Development Bank, the main financier of the project, refused to disburse any loan before the completion of land acquisition, an important step towards the financial feasibility of the

\footnotetext{
${ }^{15}$ Ma Rong, "Zhongguo yinxie cheng yidaiyilu xiangmuchubei fengfu, touzi weishou zibenguanzhi zhengce yingxiang”, Reuters, May 11, 2017, https://cn.reuters.com/article/china-cba-beltandroad-0511-thursdayidCNKBS1870HJ

${ }^{16}$ Umair Jamal, "What Pakistan's Decision to Pull Out of a Mega Dam Project Tells Us About the Future of CPEC," the Diplomat, January 11, 2018, https://thediplomat.com/2018/01/what-pakistans-decision-to-pullout-of-a-mega-dam-project-tells-us-about-the-future-of-cpec/
} 
project. ${ }^{17}$ After all, it was the policy bank that had to offer credits and be responsible for the repayment of the loans.

The economic statecraft literature suggests that the state may control economic actors through ownership and personnel appointment (Norris 2016). This is true, but it does not necessarily lead to the conclusion that the party state deploys the policy banks to pursue non-economic objectives through such means of control. In terms of ownership, the CDB is indeed a state-owned shareholding corporation. As of 2018, its four shareholders were the Ministry of Finance (MOF), Central Huijin (a sovereign wealth fund), Buttonwood investment platform of the State Administration of Foreign Exchange, and the National Council for Social Security Fund. Chexim's owners were MOF and the Buttonwood investment platform. The ownership structures added to the fragmentation of the state since these shareholders were all powerful state agencies with their own priorities. ${ }^{18}$ It is rather unlikely that they force the banks to pursue political, foreign policy, or security objectives since they are more concerned with financial conditions of their assets.

In terms of personnel appointment, all top leaders of the policy banks were appointed by the communist party. Nonetheless, these top-level officials' work experience before joining the banks reflected the preference of the party state that policy banks should prioritize economic objectives over political ones. ${ }^{19}$ As of 2018, the CDB had 13 directors (i.e., top-level leaders). Three of them were executive directors directly managing the bank, including the head of the bank. All three came from state-owned commercial banks. Four of the directors were government-agency directors from four government ministries, i.e., the National Development and Reform Commission (NDRC), MOF, MOFCOM, and the central bank. NDRC has an incentive to implement the state's industrial policies and secure resources, whereas all other government organs are more concerned with monetary, financial, and economic issues. The other six were equity directors from the four shareholders mentioned above. Similarly, of the thirteen Chexim top-level directors, all three executive directors came from the banking sector, four government-agency directors came from NDRC, MOF, MOFCOM, and the central bank, and six equity directors came from Chexim's shareholders. In other words, the party did not appoint any top-level bank official who came from a foreign policy or diplomatic background. Such a leadership structure shows that the party prioritizes economic and development tasks over foreign policy ones for the banks. The appointed bank officials must follow the party's guidelines, but their career advancement is determined more by the banks' financial performance than foreign-affair performance.

To summarize, economic statecraft theory explains China's ODF in the sense that economic actors follows the party state's general policy agendas. But the party state's agendas are broad, which leads to fragmentation in the process of implementation.

\footnotetext{
17 "Yawan Gaotie gongcheng jinzhan huanman tanxi", Liu Zixun, The Statecraft Institution, November 21, 2018, http://www.daguoce.org/article/9/400.html

"Yawan zhikun: xiangmu zhengdi weihe ruci jiannan," July 8, 2019, Power China, https://14j.powerchina. $\mathrm{cn} /$ art/2019/7/8/art 7459 601311.html

${ }^{18}$ Ownership information of the two policy banks can be found in their annual reports.

${ }^{19}$ Leadership information of the two policy banks can be found in their annual reports.
} 
Executive agencies such as ministries and policy banks have their own priorities, which do not necessarily align with foreign policy, geopolitical, or security goals all the time. Evidence shows that policy banks weighed financial feasibility to a considerable extent and might refuse to lend to a financially nonviable project regardless of its diplomatic significance.

\section{China as a Developmental State}

The developmental state literature provides another perspective to understand China's ODF. This literature captures a strong state that coordinates financial sector and channels preferential credits to selected industries and firms. The Chinese means of ODF shares many similarities with the developmental state model, especially in two aspects: (1) that it is coordinated by elite bureaucracy - ministries with resources and executive powers, and (2) that capital is channeled to a group of industries and enterprises selected by the state. Nonetheless, China's ODF capital is rather costly, which differs from subsidized, low-cost capital captured in the literature.

China's government ministries have played crucial roles in coordinating industrial policies and firms' overseas economic activities. A close examination of the banks' lending process reveals the coordinating role of key ministries. Chinese contractors (i.e., companies building infrastructure works overseas) that intend to participate in international tenders must acquire specific documents from state organs. A first document is a "Letter of Support" from China's Economic and Commercial Chancellor's Office (ECCO) in the country where tender takes place. ECCOs are the overseas offices of MOFCOM that coordinate business activities in host countries. After receiving a Letter of Support, the firm needs to acquire a "Letter of Interest in Lending" from Chinese banks and a "Letter of Interest in Insuring" from Chinese insurance companies. With these three documents, the firm can apply for a Certificate of Approval to MOFCOM's Department of Outward Investment and Economic Cooperation. ${ }^{20}$ This means that MOFCOM has the authority to veto a project. Since Chinese banks and insurance companies would not provide financial support for firms without MOFCOM's approval, only if a firm has sufficient capital to conduct a project can it possibly skip these processes. But this happens rarely because most international projects need large volumes of capital. In addition to MOFCOM, several other government organs are involved in regulating overseas finance. The NDRC coordinates Chinese firms' outward direct investment. A firm that plans to conduct cross-border mergers and acquisitions has to register with the NDRC or its provincial administrations; otherwise, banks would not lend to the firm. ${ }^{21}$ The State-Owned Assets Supervision and Administration Commission (SASAC) supervises economic performance of state-owned enterprises (SOE), i.e., how well they manage state assets.

As captured in the developmental state model, most of China's ODF loans were lent to large firms conducting business in strategic industries. Many of these firms are central enterprises, i.e., the most important SOEs directly supervised by SASAC.

\footnotetext{
20 "Duiwai Chengbao Gongcheng Xiangmu Toubiao (Yibiao) Guanli Banfa," MOFCOM, http://www. mofcom.gov.cn/article/swfg/swfgbi/201112/20111207878964.shtml.

${ }^{21}$ More details see "Qiye Jingwai Touzi Guanli Banfa," NDRC, http:/www.ndrc.gov.cn/zcfb/zcfbl/201712 /t20171226_871560.html.
} 
SASAC's 2017 central-enterprise portfolio listed 97 enterprises involved in industries relating to resources (petroleum, coal, steel, mineral, etc.), electricity, telecommunication, transportation, manufacture, and among others. ${ }^{22}$ By the end of 2014, the CDB has accumulated on-balance foreign-currency loans of US\$267 billion. About one quarter of this, approximately $\$ 67$ billion, was issued by the CDB main bank (as opposed to the CDB branches), the CDB organ that handled central enterprises' projects only (CDB Almanac 2015). ${ }^{23}$ In other words, at least a quarter of the banks' overseas loans were lent to central enterprises.

Nevertheless, the relatively high cost of Chinese ODF credits contrasts with what captured in the developmental state literature, i.e., accessibility to low-cost capital allowed selected industries and firms to have an advantage when competing with their foreign rivals. This does not apply to China's case in two aspects. First, as discussed earlier, the majority of Chinese loans are not subsidized. Second, and quite counterintuitively, Chinese firms supported by policy-bank loans are not necessarily rivaling foreign competitors from more advanced economies. A common view shared by loan managers and firm employees engaged in international infrastructure finance was that more often Chinese firms were competing with their compatriots in relatively less developed regions. Figures in the previous sections have shown that China's policy banks were mostly targeting middle-income developing countries, whereas their counterparts from industrial countries were targeting more advanced markets (Figs. 4, 5, 6, and 7).

\section{Rewriting Development Finance}

What explains the bulk of non-subsidized policy-bank loans in developing countries, if economic statecraft and developmental state literature cannot explain them? This section offers another perspective, arguing that China's peculiar means of ODF can be seen as the internationalization of a domestically originated model that has facilitated China's own growth in the past decades. Unlike conventional means of development finance, which relies on the state's role in transferring wealth from donors to recipients, China's financing model downplays the state's role in direct fiscal re-allocation and employs market means to supplement the state's fiscal capacity.

The association between concessionality and development finance, or between hierarchical aid-giving and development, was crafted in the first two decades of the postwar era by major industrial powers and the international organizations that determined the flow of credits for international development (Kapur et al. 1997; Mawdsley 2012; Schmelzer 2014; Xu 2017). This means of development finance is only feasible when donor has sufficient fiscal revenue, since a loan with any level of concessionality implies a transfer of taxpayers' money from donor to recipient countries. It does not hold, however, if the donor per se is a developing country lacking sufficient revenue to finance its own infrastructure projects. In the early 1990s, the central government of China had a large fiscal shortage (Wong 2013). The dearth of capital incentivized a

\footnotetext{
22 “Yangqi Minglu," SASAC, http://www.sasac.gov.cn/n2588035/n2641579/n2641645/index.html.

23 The CDB's provincial branches are located mostly in the capital or major port city of each province of China. Each branch is assigned a few countries and disburses loans to projects taking place in their assigned countries only. The only department of the CDB main bank that directly disburses loans is the Enterprise Bureau, which is in charge of all projects relating central enterprises.
} 
series of fiscal and financial reforms, including the establishment of policy banks in 1994 to make more efficient use of limited capital. In other words, the mission of the policy banks from the very beginning was to diverge from a public-finance system that relied solely on the allocation of fiscal revenue.

Starting in the late 1990s, the CDB began to restructure its lending arrangements, aiming to transform from a sheer credit allocator of the state to a "real" bank that could make its own lending decisions. A result of the restructuring was the creation of a set of internal institutions that appraise projects' credibility and evaluate their risks. A loan request therefore had to go through financial scrutiny and voting procedure by multiple bureaus and committees of the bank in order to be approved. The birth of this internal project-selection system justified and enabled the bank's veto of government-assigned, financially nonviable projects. In other words, with its own decision-making criteria, the CDB began to say no to the government organs that used to determine the finance of infrastructure projects in China (Chen 2012; Sanderson and Forsythe 2013; CDB 2016b). "We have to tell people over and over again. If the bad loans accumulate then one day we won't be able to lend, so that will be bad for everybody. And gradually they began to accept," said Chen Yuan, the CDB governor that initiated the banks' major institutional changes in the late 1990s and 2000s (Sanderson and Forsythe 2013: 59).

Compared to the CDB, Chexim is more "government-led" in the sense that a small part of its lending is government-subsidized concessional loans. Nevertheless, this does not mean that Chexim is willing to sacrifice financial viability. The bank shares a historically rooted character with the CDB in deviating from a fiscal-centric credit allocation system and pursuing financial sustainability as an independent bank. In the 2000 s, Chexim went through a series of internal restructuring to enhance its financial profitability. "Chexim used to run a deficit because the interest rate of its policyoriented concessional lending was lower than the cost of its fundraising, the yield of its bonds," said Li Ruogu, former governor of Chexim, "since 2006 the bank began to have self-run business, which interest rates were determined by market rates. This part of business made up the losses caused by concessional lending, and allowed the bank to 'break even with earning small profit"' (Zhang 2010).

To maintain a financial balance and ensure loan repayments, the policy banks employed various financial means to enhance creditworthiness of projects. Theoretically, a bankable project generates sufficient cash flow by itself and uses such cash flow to repay loans. For example, a highway project may use tolls to repay loans. For projects that do not generate sufficient cash flow, which is common in infrastructure financing, the banks would request an extra level of guarantee from the borrower (a government organ) to raise the credit level of projects and cover extra risks. Inside China, provincial and municipal governments lacking sufficient revenue used state-owned land, government properties, future revenues, and various forms of assets as guarantees and collaterals when applying for bank loans to finance their infrastructure projects. Adding government guarantees was not the only way to enhance projects' credibility. As mentioned earlier, the CDB used bundled loans to conduct portfolio financing, i.e., lending to multiple projects at a time. This allowed the bank to use earnings from the more profitable projects to cover losses of the less profitable ones. But to be able to finance and bundle several projects, the bank must plan ahead of time in coordination with the borrowing government, rather than participate in tenders after the government announced projects. In other words, bankgovernment coordination was crucial for portfolio financing. 
What reflected in these financial techniques was a mutually constitutive view of state-market relations. As articulated in the autobiography of Chen Yuan, development finance should be conducted in accordance with market rules and banking regulations; the state should not determine every aspect of infrastructure finance, but should be actively involved in establishing market institutions that allow infrastructure finance to take place (Chen 2012). For domestic infrastructure projects, China's provincial and municipal governments offered indirect support in forms of guarantees, collaterals, and coordination, whereas direct fiscal input has been reduced to a minimal level.

This "state-supported, market-based" financing mechanism was practiced overseas as the CDB launched its international adventure starting in the early 2000s and soon followed up by Chexim. "A province of China is no smaller than many medium-sized countries. If we can plan well for a province, we can do the same for a country," said Chen Yuan (Chen 2012: 104). When conducting overseas business, policy banks would negotiate with host country's government organs ahead of time, exploring possible ways of enhancing project's credibility, if financially nonviable. Requesting revenuebased guarantee has been a common practice, but not all governments are willing to do this because this would increase their debt level and affect their credibility when borrowing from other international financial agencies. For borrowers that lacked the capacity to repay their loans with capital, policy banks allowed commodity-backed repayment, which required an even higher degree of coordination. It not only involved banks and government, but also contractors building infrastructure works as well as firms trading commodities.

A widely known example was the CDB's oil-backed loans to Venezuela, which has drawn much scholarly and media attention (Downs 2011; Gallagher et al. 2012; Sanderson and Forsythe 2013; Bräutigam and Gallagher 2014). In 2007, China and Venezuela jointly established a fund, where the CDB lent $\$ 4$ billion and the Venezuelan Economic and Social Development Bank (Venezuela's development bank) invested \$2 billion. ${ }^{24}$ The fund capitalized oil-backed lending, which process consisted of two parts. The first part was international contracting-CDB loans were used to pay Chinese contractors that built infrastructure in Venezuela. The second part was oilbacked repayment. The CDB signed a contract with PDVSA, a Venezuelan stateowned oil and natural gas company; PDVSA sold oil to Chinese SOEs, the SOEs paid for the oil to a CDB account, and their payment was used to repay loans owed by Venezuela. In essence, the CDB was using Venezuela's future oil revenue to repay the loans, and China was offering infrastructure in exchange for oil. This model was therefore dubbed the "infrastructure-for-oil" model.

The story was often depicted as an evidence of economic statecraft, i.e., China employed its financial agency to secure energy overseas and strengthen political ties with borrowing countries. This is to a large extent true, but one important aspect has often been overlooked in the narrative. The party state was not the one that initiated the projects; it was the internationalization of the CDB's development-finance that drove this particular means of collaboration on the ground. In an interview with Modern Bankers, Chen Yuan disclosed the process the joint fund came into being. During its internationalization in the 2000s, the CDB sent out bank officials to search for business

\footnotetext{
24 "Yu Woguo Zhu Weineiruila Dashiguan Jingsancanchu Wangyong Canzan Wangshang Jiaoliu," MOFCOM, http://shangwutousu.mofcom.gov.cn/article/lbqz/lbzn/200911/20091106631648.shtml.
} 
opportunities overseas. "After three months, the overseas working group in Venezuela reported that Chavez would visit China, and would like to see me. Chavez and I talked for half an hour and he asked at the end of the conversation if we could establish a China-Venezuela cooperation fund," recalled Chen, "I said yes but you need to talk to the president. He met President Hu (then the president of China) in the afternoon and the president agreed with the suggestion. That was the start of our lending to Venezuela" (Chen 2019: 22-28). The bank designed the details of the lending. From a lender's perspective, oil served as a type of collateral that allowed commercially nonviable infrastructure projects in less developed countries to take place. "The Chavez administration was powerful, and we were able to request multiple collaterals from it," said a former senior CDB official. ${ }^{25}$

The CDB was not the first Chinese bank that practiced this model. Chexim employed the same model with its oil-backed lending to Angola, which was named "the Angola Mode" by the World Bank (Foster et al. 2009).The infrastructure-for-oil model or the Angola Mode was largely criticized by mass media as a failed investment or China's debt trap, when commodity prices dropped dramatically and borrowers could not repay their loans. This paper does not seek to evaluate this model, but to point out the core idea behind all the above-mentioned financial techniques that the policy banks employed to fund infrastructure. Fiscal guarantees, portfolio financing, government-backed collaterals, and commodity-based repayment were means of "credit supports" that enhanced the creditworthiness of non-bankable projects in countries lacking sufficient fiscal revenue. These financing methods involved risks in their very original design, since the policy banks were essentially allowing the state to cover extra risks for projects that would otherwise not have passed banking appraisal according to commercial standards. Yet, at the same time, credit enhancement enabled less developed countries with neither sufficient fiscal revenue nor attractiveness to commercial capital to borrow money and build infrastructure projects.

Understanding the state-market relations reflected in policy banks' financing mechanisms paves the way to understanding the peculiarity of China's ODF, i.e., financing developing countries with relatively high-interest rate loans. The banks mostly targeted developing economies because many of their governments, like China's subnational governments, did not have sufficient revenue to finance infrastructure projects needed for industrialization and urbanization. The banks lent on commercial rates because from their perspective infrastructure financing was not fiscal spending, and the money lent needed to be repaid with interests sufficiently high to allow the banks to maintain financial balances. Yet, the lending process was not free of state participation - the state facilitated the transactions in an indirect way. If projects were not financially viable, host countries' government organs enhanced their credibility and made them "bankable."

\section{Conclusion}

Examining the lending mechanisms of the policy banks, this paper shows that the bulk of non-subsidized Chinese ODF can be understood as the internationalization of a financing model that has facilitated China's own development in the past decades. This

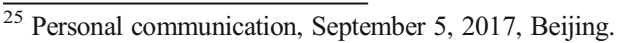


model differs from traditional means of aid-giving in that it downplays the role of the state in allocating fiscal revenue. It also differs from the model captured in the developmental state literature, in which the state subsidizes firms' international competition. The policy-bank loans instead demonstrate a new means of state involvement in development-not directly channeling capital, but enhancing the credibility of projects through indirect support, such as offering guarantees, collateralizing assets, and coordinating various parties. This "state-supported, market-based" means of development finance allows developing countries which (1) lack the fiscal capacity to directly finance infrastructure, (2) do not appeal sufficient commercial investment, and (3) receive limited amounts of aid or concessional lending from traditional donors to be able to finance infrastructure.

Nonetheless, whether this peculiar means of ODF will sustain in the long run remains questionable. As the paper shows, policy banks' financing mechanism originated from China's own experience growing as a developing economy, one that needed capital to urbanize and industrialize but lacked the fiscal capacity to capitalize such processes. As the government's fiscal capacity enhances, China may be able to employ larger amount of fiscal revenue and offer more concessional lending and may be able to practice development finance the way most OECD donors do. In 2018, the China International Development Cooperation Agency was inaugurated, integrating the respective coordinating roles of China's Ministry of Commerce and Ministry of Foreign Affairs over foreign assistance. The goal of this agency, according to official document, is to allow foreign assistance to play an important role in China's foreign diplomacy. ${ }^{26}$ Although it remains unclear whether the state will channel significant volume of fiscal credits directly to this new agency to finance international development, surpassing the volume of policy-bank loans, the creation of this agency indicates a possibility for increasing state-led concessional lending. Whether and how long China's current means of development financing will sustain therefore requires further examination.

Acknowledgments The author thanks the Global Development Policy Center for a Pre-Doctoral Fellowship that supported the writing of the first draft of this article. The author thanks the participants in the following events for their constructive feedback on earlier versions of this article: China Global Research Colloquium, Boston University, 2018; the author's job talk at the School of International Studies, Peking University, 2018; International Studies Association Annual Convention, 2019; and Society for the Advancement of SocioEconomics Annual Conference, 2019. The author also thanks David Bachman, Marie Anchordoguy, Susan Whiting, Sarah Quinn, Kevin P. Gallagher, Jiajun Xu, Tobias ten Brink, and editors and anonymous reviewers of Studies in Comparative International Development for their helpful comments and criticisms.

Open Access This article is licensed under a Creative Commons Attribution 4.0 International License, which permits use, sharing, adaptation, distribution and reproduction in any medium or format, as long as you give appropriate credit to the original author(s) and the source, provide a link to the Creative Commons licence, and indicate if changes were made. The images or other third party material in this article are included in the article's Creative Commons licence, unless indicated otherwise in a credit line to the material. If material is not included in the article's Creative Commons licence and your intended use is not permitted by statutory regulation or exceeds the permitted use, you will need to obtain permission directly from the copyright holder. To view a copy of this licence, visit http://creativecommons.org/licenses/by/4.0/.

\footnotetext{
${ }^{26}$ The agency was established according to a document issued by the Communist Part of China titled "Deepening the Reform Plan of Party and State Institutions", 2018, Central Government of PRC, http://www.gov.cn/zhengce/2018-03/21/content_5276191.htm\#allContent (accessed April 10, 2020).
} 


\section{References}

Almanac of China's Finance and Banking Editorial Board. Almanac of China's Finance and Banking [Zhongguo Jinrong Nianjian]. Beijing: China Financial Publishing House; 2014.

Almanac of China's Finance and Banking Editorial Board. Almanac of China's Finance and Banking [Zhongguo Jinrong Nianjian]. Beijing: China Financial Publishing House; 2015.

Alves AA. Chinese economic statecraft: a comparative study of China's oil-backed loans in Angola and Brazil. J Curr Chin Aff. 2013;42:99-130.

Amsden A. Asia's next giant. New York: Oxford University Press; 1989.

Amsden A. The rise of "the rest": challenges to the west from late-industrializing economies. New York: Oxford University Press; 2001.

Baldwin D. Analytical notes on foreign aid and politics. Int Stud Q. 1966;10:66-90.

Baldwin D. Economic Statecraft. Princeton: Princeton University Press; 1985.

Bauer PT. Dissent on Development. Scot J Polit Econ. 1968;16:75-94.

Bräutigam D. Aid 'with Chinese characteristics': Chinese foreign aid and development finance meet the OECD-DAC aid regime. J Int Dev. 2011;23:752-64.

Bräutigam D, Gallagher KP. Bartering globalization: China's commodity-backed finance in Africa and Latin America. Glob Policy. 2014;5:346-52.

Chen Y. Zhengfu yu shichang zhijian: kaifaxing jinrong de zhongguo tansuo [Between Government and Market: China's Exploration on Development Finance]. Beijing: Zhongxin Chubanshe [CITIC Publishing Group]; 2012.

Chen Y. Jianzheng guojia 40nian jinrong gaige de rongyao [witnessing the glory of the country's 40-year financial reform]. Mod Bankers. 2019;4:22-8.

Chen M. State actors, market games: credit guarantees and the funding of China Development Bank. New Political Economy. 2020;25:453-68.

Chin GT, Gallagher KP. Coordinated credit spaces: the globalization of Chinese development finance. Dev Chang. 2019;50:245-74.

Chin GT, Quadir F. Introduction: rising states, rising donors and the global aid regime. Camb Rev Int Aff. 2012;25:493-506.

China Development Bank. China Development Bank History 1994-2012 [Guojia Kaifa Yinhangshi 1994 2012]. Beijing: China Financial Publishing House; 2013.

China Development Bank. China Development Bank Almanac. Beijing: China Financial Publishing House; 2015.

China Development Bank, China Development Bank Annual Report; 2016a. Available from: http://www.cdb. com.cn/bgxz/ndbg/ndbg2016/. Accessed 1 Aug 2018.

China Development Bank. Popular words of development finance [Kaifaxing Jinrong Reci]. Beijing: People's Daily Press; 2016b.

China Export \& Credit Insurance Corporation. Sinosure Annual Report; 2015.

Downs E. Inside China, Inc: China Development Bank's cross-border energy deals. In: John L. Thornton China Center Monograph Series. Washington, D.C.: Brookings Institute; 2011.

Dreher A, et al. Aid, China, and growth: evidence from a new global development finance dataset. AidData working paper \#46. Williamsburg: AidData at William \& Mary; 2017.

Easterly W. Can foreign aid buy growth? J Econ Perspect. 2003;17:23-48.

Easterly W. The white Man's burden: why the West's efforts to aid the rest have done so much ill and so little good. New York: Penguin Books; 2006.

Edwards S. Economic development and the effectiveness of foreign aid: a historical perspective. NBER Working Paper No. 20685; 2014.

Evans P. Embedded autonomy: states and industrial transformation. Princeton: Princeton University Press; 1995.

Foster V, et al. Building bridges: China's growing role as infrastructure financier for Sub-Saharan Africa. Trends and policy options No. 5. World Bank; 2009.

Gallagher KP, et al. The new banks in town: Chinese finance in Latin America: Inter-American Dialogue, Washington, D.C.; 2012.

Haggard S. Developmental states: Cambridge University Press; 2018.

Haggard S, et al. The politics of finance in developing countries. Ithaca: Cornell University Press; 1993.

Hopewell K. Power transitions and global trade governance: the impact of a rising China on the export credit regime. Regulation Gov. 2019. https://doi.org/10.1111/rego.12253. 
Japan Bank of International Cooperation. Annual Report; 2016. Available from: https://www.jbic.go. jp/en/information/annual-report.html. Accessed 1 Aug 2018.

Japan International Cooperation Agency. Annual Report; 2016. Available from: https://www.jica.go. jp/english/publications/reports/annual/index.html. Accessed 1 Aug 2018.

Johnson C. MITI and the Japanese miracle: the growth of industrial policy, 1925-1975. Stanford: Stanford University Press; 1982.

Jones L, Zou Y. Rethinking the role of state-owned Enterprises in China's rise. New Polit Econ. 2017;22:74360.

Kapur D, et al. The World Bank: its first half century. Washington, DC: Brookings Institution Press; 1997.

Katada SN, Liao J. China and Japan in pursuit of infrastructure development leadership: competition or convergence?. Global Governance forthcoming.

KfW. KfW Promotional Figures; 2016. Available from: https://www.kfw.de/PresseNewsroom/Pressematerial/PDF-Dateien-Pr\%C3\%A4sentationen/PDF-Dokumente-2016/LAY_KfW Geschaefts_Foerdertabellen_2017_f_Jahreskonferenz_DE_170130_03-2.pdf. Accessed 1 Aug 2018.

KfW-IPEX Bank. Annual Report; 2016. Available from: https://www.kfw-ipex-bank.de/Internationalfinancing/KfW-IPEX-Bank/Presse/Download-Center/Annual-report/. Accessed 1 Aug 2018.

Kitano, Naohiro. Estimating China's Foreign Aid II: 2014 Update. JICA Research Institute Working Paper No.131; 2016.

Kitano N, Harada Y. Estimating China's foreign aid 2001-2013. JICA research institute working paper, No. 78; 2014,

Lewis WA. Economic development with unlimited supplies of labour. Manch Sch. 1954;22:139-91.

Li X, Zeng K. To join or not to join? State ownership, commercial interests, and China's belt and road initiative. Pac Aff. 2019;92:5-26.

Liao J. A good neighbor of bad governance? China's energy and infrastructure development in Southeast Asia. J Contemporary China. 2019;28:575-91.

Lin JY, Wang Y. Going Beyond aid: development cooperation for structural transformation. Cambridge: Cambridge University Press; 2017.

Liou CS. Rent-seeking at home, capturing market share abroad: the domestic determinants of the transnationalization of China state construction engineering corporation. World Dev. 2014;54:220-31.

Liska G. The new statecraft: foreign aid in American foreign policy. Chicago: University of Chicago Press; 1960.

Mastanduno M. Economic statecraft, interdependence, and national security: agendas for research. Secur Stud. 1999;9:288-316.

Mawdsley E. From recipients to donors: emerging powers and the changing development landscape. London. New York: Zed Books; 2012.

Morgenthau H. A political theory of foreign aid. Am Polit Sci Rev. 1962;56:301-9.

Norris W. Chinese economic statecraft: commercial actors, grand strategy, and state control. Ithaca: Cornell University Press; 2016.

Ohno K, Ohno I. Eastern and Western ideas for African growth diversity and complementarity in development aid. London: Routledge; 2013.

Reilly J. China's economic statecraft: turning wealth into power. The Lowy Institute for International Policy; 2013.

Rosenstein-Rodan PN. International aid for underdeveloped countries. Rev Econ Stat. 1961;43:107-38.

Rostow WW. Economics of take-off into sustained growth. London: Palgrave Macmillan; 1963.

Sanderson H, Forsythe M. China's superbank: debt, oil and influence-how China development bank is rewriting the rules of finance. Singapore: Wiley; 2013.

Sato J, Shiga H, Kobayashi T, Kondoh H. Emerging donors' from a recipient perspective: an institutional analysis of foreign aid in Cambodia. World Dev. 2011;39:2091-104.

Schmelzer M. A Club of the Rich to help the poor? The OECD, "development", and the hegemony of donor countries. In: Frey M, Kunkel S, Unger CR, editors. International organizations and development, 19451990. London: Palgrave Macmillan; 2014.

Six C. The rise of postcolonial states as donors: a challenge to the development paradigm?. Third World Q 2009; 3;0: 1103-1121.

Solís M. Banking on multinationals: public credit and the export of Japanese sunset industries. Stanford: Stanford University Press; 2004.

Stallings B, Kim EM. Promoting development: the political economy of east Asian foreign aid. Singapore: Palgrave; 2017.

The State Council of People's Republic of China. China's foreign assistance white paper 2014 (Zhongguo de Duiwai Yuanzhu 2014). Available at http://www.gov.cn/zhengce/2014-07/10/content_2715467.htm. 
Thurbon E. Developmental mindset: the revival of financial activism in South Korea. Ithaca: Cornell University Press; 2016.

Wade R. Governing the market: economic theory and the role of government in east Asian industrialization. Princeton: Princeton University Press; 1990.

Wong C. Reforming China's public finances for long-term growth. In: Garnaut R, Fang C, Song L, editors. China: a new model for growth and development. Canberra: ANU Press; 2013. p. 199-219.

Woo-Cumings M. The developmental state. Ithaca: Cornell University Press; 1999.

$\mathrm{Xu}$ J. Beyond US Hegemony in international development: the contest for influence at the World Bank. Cambridge: Cambridge University Press; 2017.

$\mathrm{Xu}$ J, Carey R. Post-2015 global governance of official development finance: harnessing the renaissance of public entrepreneurship. J Int Dev. 2015;27:856-80.

Ye M. Fragmentation and mobilization: domestic politics of the belt and road in China. J Contemp China. 2019;28:696-711.

Zhang Z. Li Ruogu xiangjie jinchukou yinhang zhilu. Century Weekly; 2010. Available at http://magazine. caixin.com/2010-06-06/100150319.html. Accessed 8 Apr 2020.

Zou L. China's rise: development-oriented finance and sustainable development. Singapore: World Scientific; 2014.

Publisher's Note Springer Nature remains neutral with regard to jurisdictional claims in published maps and institutional affiliations.

Muyang Chen is an Assistant Professor at the School of International Studies, Peking University. Her research focuses on infrastructure finance, development banking, state-market relations, and international development. 